\title{
(6) OPEN ACCESS \\ Differences in incidence of diabetic retinopathy between type 1 and 2 diabetes mellitus: a nine-year follow-up study
}

\author{
Pedro Romero-Aroca, ${ }^{1,2}$ Raul Navarro-Gil, ${ }^{1,2}$ Aida Valls-Mateu, ${ }_{1}^{3}$ \\ Ramon Sagarra-Alamo, ${ }^{4}$ Antonio Moreno-Ribas, ${ }^{3}$ Nuria Soler ${ }^{1,2}$
}

\begin{abstract}
${ }^{1}$ Ophthalmology Service, University Hospital Sant Joan, Reus, Spain

${ }^{2}$ Institut de Investigacio Sanitaria Pere Virgili (IISPV), Universitat Rovira and Virgili, Reus, Spain

${ }^{3}$ Department of Computer Engineering and Mathematics, Universitat Rovira and Virgili, Reus, Spain

${ }^{4}$ Health Care Area Reus-Priorat, Institut Catala de la Salut (ICS), Institut de Investigació Sanitària Pere Virgili (IISPV), Universitat Rovira and Virgili, Reus, Spain
\end{abstract}

Correspondence to Dr Pedro Romero-Aroca Hospital Universtario Sant Joan, Avenida, Doctor, Josep Laporte 2, Reus 43204, Spain

romeropere@gmail.com promero@grupsagessa.com

Received 14 December 2016 Revised 31 January 2017 Accepted 10 February 2017 Published Online First 7 March 2017

\section{CrossMark}

To cite: Romero-Aroca $\mathrm{P}$ Navarro-Gil R, Valls-Mateu A et al. Br J Ophthalmol 2017;101:1346-1351.

\begin{abstract}
Background/aims To determine the incidence of any diabetic retinopathy (any-DR), sight-threatening diabetic retinopathy (STDR) and diabetic macular oedema (DMO) and their risk factors in type 1 diabetes mellitus (T1DM) over a screening programme.
\end{abstract}

Methods Nine-year follow-up, prospective populationbased study of 366 patients with T1DM and 15030 with T2DM. Epidemiological risk factors were as follows: current age, age at DM diagnosis, sex, type of DM, duration of DM, arterial hypertension, levels of glycosylated haemoglobin $\left(\mathrm{HbA}_{1 \mathrm{c}}\right)$, triglycerides, cholesterol fractions, serum creatinine, estimated glomerular filtration rate (eGFR) and urine albumin to creatinine ratio (UACR)

Results Sum incidence of any-DR was $47.26 \%$ with annual incidence $15.16 \pm 2.19 \%$ in T1DM, and $26.49 \%$ with annual incidence $8.13 \%$ in T2DM. Sum incidence of STDR was $18.03 \%$ with annual incidence 5.77 $\pm 1.21 \%$ in T1DM, and $7.59 \%$ with annual incidence $2.64 \pm 0.15 \%$ in T2DM. Sum incidence of DMO was $8.46 \%$ with annual incidence $2.68 \pm 038 \%$ in patients with T1DM and $6.36 \%$ with annual incidence 2.19 $\pm 0.18 \%$ in T2DM. Cox's survival analysis showed that current age and age at diagnosis were risk factors at $p<0.001$, as high $\mathrm{HbA} 1 \mathrm{c}$ levels at $\mathrm{p}<0.001, \mathrm{LDL}$ cholesterol was significant at $p<0.001$, eGFR was significant at $p<0.001$ and UACR at $p=0.017$.

Conclusions The incidence of any-DR and STDR was higher in patients with T1DM than those with T2DM. Also, the $47.26 \%$ sum incidence of any-DR in patients with T1DM was higher than in a previous study (35.9\%), which can be linked to poor metabolic control of DM. Our results suggest that physicians should be encouraged to pay greater attention to treatment protocols for T1DM in patients.

\section{INTRODUCTION}

It is estimated that more than 200 million people worldwide currently have diabetes and that number is predicted to rise by over $120 \%$ by $2025 .^{1}$ It has become a chronic disease with several complications. Diabetes mellitus (DM) is classified as type 1 diabetes (T1DM) or type 2 diabetes (T2DM), gestational diabetes, monogenic diabetes and secondary diabetes. ${ }^{2}$ There is a current trend towards more children developing T1DM and more than half a million children are estimated to be living with the disease.

The most important ocular complication is diabetic retinopathy (DR), a common cause of blindness in Europe. ${ }^{3}$ Development of DR is similar in both DM types. DR screening uses a non-mydriatic fundus camera, a cost-effective way of screening DM populations. ${ }^{4}$ Screening frequency varies according to DM type. ${ }^{5}$ Our group rolled out a screening programme in 2000 that included general practitioners and endocrinologists, ${ }^{6}$ and we reported an increase in the incidence of DR in a previously published study.

In this study, we determine the incidence of any-DR, sight-threatening retinopathy (STDR) and diabetic macular oedema (DMO) in patients with T1DM and its differences in patients with T2DM.

\section{MATERIALS AND METHODS}

Setting: The reference population in our area is 247174 . The total number of patients with DM registered with our healthcare area is 17792 (7.1\%).

Design: A prospective, population-based study, conducted from 1 January 2007 to 31 December 2015. A total of 366 patients with T1DM and 15 030 with T2DM were screened.

Power of the study: Our epidemiologist estimates the detection of a $\pm 3 \%$ increase in risk and $95 \%$ accuracy.

Method: Screening for DR was carried out with one $45^{\circ}$ field retinography, centred on the fovea. If DR was suspected, a total of nine retinographies of $45^{\circ}$ were taken and a complete screening is described elsewhere. ${ }^{8}$ Due to the difficulty in obtaining images from patients with T1DM under 12 years old, only those aged $>12$ years were included.

In this study, DR is classified into (i) no-DR, (ii) any-DR-level 20-35 of the ETDRS, (iii) STDRdefined as level 43 or worse by the ETDRS. The term 'DMO' includes 'extrafoveal' and/or 'clinically significant macular oedema (CSMO)' according to the ETDRS classification. ${ }^{9}$

Measures of kidney diabetic disease were determined by (i) serum creatinine; (ii) estimated glomerular filtration rate (eGFR), measured by the chronic kidney disease epidemiology collaboration equation (CKD-EPI); (iii) urine albumin to creatinine ratio (UACR), classified in normoalbuminuria defined as UACR $<30 \mathrm{mg} / \mathrm{g}$, microalbuminuria as UACR $30-299 \mathrm{mg} / \mathrm{g}$ and macroalbuminuria as UACR $\geq 300 \mathrm{mg} / \mathrm{g}$.

At the end of the study, all patients with T1DM were visited, and a fundus nine-field retinographies was carried out by an ophthalmologist to confirm the number of patients with DR and if any new patients with DR are previously not diagnosed.

Inclusion criteria: Patients with T1DM $>12$ years old, and all patients with T2DM. 
Exclusion criteria: Patients with other specific types of diabetes, and patients with gestational DM.

Ethical adherence: The study was carried with the approval of the local ethics committee (approval no. 13-01-31/proj6) and in accordance with revised guidelines of the Declaration of Helsinki.

\section{Statistical methods}

Data evaluation and analysis was carried out using SPSS V.22.0 statistical software package and $\mathrm{p}<0.05$ was considered to indicate statistical significance.

Descriptive statistical analysis of quantitative data was made by the determination of mean, SD, minimum and maximum values, and the 95\% CI. For qualitative data, we used the analysis of frequency and percentage in each category. Differences were examined using the two-tailed Student's t-test to compare two variables or using one-way analysis of variance if we were comparing more than two variables. Inferential analysis for qualitative data was made by the $\chi^{2}$ table and the determination of the Fisher test for quantitative data. Multivariate analysis was carried out using Cox survival regression analysis.

\section{RESULTS}

Demographic variables of sample size

In the 9-year follow-up (1 January 2007 to 31 December 2015), a total of 366 patients with T1DM and 15030 with T2DM were screened (table 1).
Each patient with T1DM was screened $4.11 \pm 0.77$ times over the 9 years compared with $3.19 \pm 1.12$ for each patient with T2DM.

Sample characteristics of patients with T1DM at the end of study were as follows: current age $35.19 \pm 10.03$ years, age at diagnosis 22.04 \pm 9.11 years and DM duration 13.63 \pm 8.42 years. By current age, DR did not appear in patients aged $<20$ years but was present in $27(39.70 \%)$ patients aged 20-30 years, in $74(47.74 \%)$ patients aged 30-40 years and in $66(61.11 \%)$ patients aged $>40$ years.

Mean HbA1c values were $8.38 \pm 1.16 \%$ in patients with T1DM and $7.38 \pm 1.29 \%$ in patients with T2DM. Table 2 shows the $\mathrm{HbA} 1 \mathrm{c}$ percentages according to DM duration. It is interesting to observe that $14.7 \%$ of patients with DM duration $<5$ years present DR and HbA1c percentages decrease and in patients with any-DR with an increase in DM duration, which might explain why patients with $>20$ years DM duration have only $81.08 \%$ of DR incidence.

\section{Study of differences between patients with T1DM and T2DM}

Table 1 shows differences between both DM types. Excluding differences in age, men are more frequent in both DM types but less in T1DM, being significant at $\mathrm{p}<0.001$. Also, the statistical analysis of mean differences between T1DM and T2DM, using the two-tailed Student $t$-test, was significant for diabetes duration $(p<0.001)$ and HbA1c levels $(p<0.001)$.

Table 1 Descriptive values of the sample

\begin{tabular}{|c|c|c|c|c|c|c|c|c|c|}
\hline Year & 2007 & 2008 & 2009 & 2010 & 2011 & 2012 & 2013 & 2014 & 2015 \\
\hline $\begin{array}{l}\text { Number of patients } \\
\text { with T1DM }\end{array}$ & 117 & 116 & 121 & 124 & 121 & 144 & 129 & 142 & 127 \\
\hline $\begin{array}{l}\text { Number of patients } \\
\text { with T2DM }\end{array}$ & 4910 & 4873 & 5191 & 5243 & 5264 & 6193 & 5494 & 5983 & 5026 \\
\hline T1DM men & $\begin{array}{l}75 \\
64.1 \%\end{array}$ & $\begin{array}{l}76 \\
65.5 \%\end{array}$ & $\begin{array}{l}79 \\
65.29\end{array}$ & $\begin{array}{l}81 \\
65.32 \%\end{array}$ & $\begin{array}{l}78 \\
64.46 \%\end{array}$ & $\begin{array}{l}93 \\
64.58 \%\end{array}$ & $\begin{array}{l}84 \\
65.11 \%\end{array}$ & $\begin{array}{l}93 \\
65.49 \%\end{array}$ & $\begin{array}{l}83 \\
65.35 \%\end{array}$ \\
\hline T2DM men & $\begin{array}{l}2881 \\
57.31 \%\end{array}$ & $\begin{array}{l}2802 \\
56.16 \%\end{array}$ & $\begin{array}{l}2890 \\
54.41 \%\end{array}$ & $\begin{array}{l}3007 \\
56.03 \%\end{array}$ & $\begin{array}{l}2933 \\
55.60 \%\end{array}$ & $\begin{array}{l}3594 \\
56.72 \%\end{array}$ & $\begin{array}{l}3131 \\
55.69 \%\end{array}$ & $\begin{array}{l}3511 \\
57.33 \%\end{array}$ & $\begin{array}{l}2817 \\
56.05 \%\end{array}$ \\
\hline T1DM mean age & $33.08 \pm 10.1$ & $33.11 \pm 10.01$ & $33.1 \pm 10.1$ & $34.17 \pm 10.08$ & $34.64 \pm 10.05$ & $34.86 \pm 10.02$ & $35.22 \pm 10.11$ & $35.19 \pm 10.03$ & $35.58 \pm 10.14$ \\
\hline T2DM mean age & $64.62 \pm 12.23$ & $66.27 \pm 12.32$ & $65.39 \pm 12.41$ & $65.69 \pm 11.7$ & $65.22 \pm 12.12$ & $65.33 \pm 12.08$ & $65.87 \pm 12.07$ & $65.88 \pm 11.94$ & $65.84 \pm 12.39$ \\
\hline T1DM duration & $12.74 \pm 8.69$ & $12.72 \pm 8.71$ & $12.69 \pm 8.74$ & $12.77 \pm 8.77$ & $12.79 \pm 8.67$ & $12.81 \pm 8.58$ & $12.78 \pm 8.71$ & $12.86 \pm 8.78$ & $12.81 \pm 8.77$ \\
\hline T2DM duration & $8.37 \pm 6.92$ & $8.66 \pm 6.78$ & $8.57 \pm 6.12$ & $8.23 \pm 6.81$ & $8.29 \pm 6.56$ & $8.23 \pm 6.82$ & $8.28 \pm 6.11$ & $8.34 \pm 6.83$ & $8.35 \pm 6.77$ \\
\hline T1DM mean HbA1c & $\begin{array}{l}8.28 \pm 1.51 \\
4.9-14.2\end{array}$ & $\begin{array}{l}8.31 \pm 1.49 \\
5-15.1\end{array}$ & $\begin{array}{l}8.29 \pm 1.44 \\
5-14.9\end{array}$ & $\begin{array}{l}8.33 \pm 1.47 \\
4.9-15\end{array}$ & $\begin{array}{l}8.25 \pm 1.5 \\
4.71-15\end{array}$ & $\begin{array}{l}8.40 \pm 1.4 \\
5.3-15.2\end{array}$ & $\begin{array}{l}8.32+1.22 \\
5.1-14.32\end{array}$ & $\begin{array}{l}8.59 \pm 1.3 \\
5-14.7\end{array}$ & $\begin{array}{l}8.77 \pm 1.14 \\
5.5-15.1\end{array}$ \\
\hline T2DM mean $\mathrm{HbA} 1 \mathrm{c}$ & $\begin{array}{l}7.37 \pm 1.48 \\
3.9-14\end{array}$ & $\begin{array}{l}6.82 \pm 1.24 \\
4.37-12\end{array}$ & $\begin{array}{l}7.02 \pm 1.7 \\
3.8-15\end{array}$ & $\begin{array}{l}7.47 \pm 1.5 \\
4.5-14.5\end{array}$ & $\begin{array}{l}7.3 \pm 1.5 \\
4-15.5\end{array}$ & $\begin{array}{l}7.63 \pm 1.4 \\
4.3-15.8\end{array}$ & $\begin{array}{l}7.62 \pm 1.41 \\
4.3-15.8\end{array}$ & $\begin{array}{l}7.64 \pm 1.4 \\
4-15.6\end{array}$ & $\begin{array}{l}7.61 \pm 1.5 \\
4.2-15\end{array}$ \\
\hline \multicolumn{10}{|c|}{ Incidence of $D R$ and its severity. } \\
\hline Year & 2007 & 2008 & 2009 & 2010 & 2011 & 2012 & 2013 & 2014 & 2015 \\
\hline $\begin{array}{l}\text { T1DM } \\
\text { Any-DR }\end{array}$ & $\begin{array}{l}16 \\
13.67 \%\end{array}$ & $\begin{array}{l}18 \\
15.51 \%\end{array}$ & $\begin{array}{l}17 \\
14.04 \%\end{array}$ & $\begin{array}{l}18 \\
14.51 \%\end{array}$ & $\begin{array}{l}19 \\
15.7 \%\end{array}$ & $\begin{array}{l}23 \\
15.97 \%\end{array}$ & $\begin{array}{l}20 \\
15.5 \%\end{array}$ & $\begin{array}{l}22 \\
15.49 \%\end{array}$ & $\begin{array}{l}20 \\
15.74 \%\end{array}$ \\
\hline $\begin{array}{l}\text { T2DM } \\
\text { Any-DR }\end{array}$ & $\begin{array}{l}390 \\
7.94 \%\end{array}$ & $\begin{array}{l}384 \\
7.88 \%\end{array}$ & $\begin{array}{l}411 \\
7.06 \%\end{array}$ & $\begin{array}{l}424 \\
8.05 \%\end{array}$ & $\begin{array}{l}407 \\
7.73 \%\end{array}$ & $\begin{array}{l}533 \\
8.6 \%\end{array}$ & $\begin{array}{l}489 \\
8.9 \%\end{array}$ & $\begin{array}{l}529 \\
8.84 \%\end{array}$ & $\begin{array}{l}415 \\
8.25 \%\end{array}$ \\
\hline T1DM STDR & $\begin{array}{l}6 \\
5.13 \%\end{array}$ & $\begin{array}{l}7 \\
6.03 \%\end{array}$ & $\begin{array}{l}7 \\
5.78 \%\end{array}$ & $\begin{array}{l}8 \\
6.45 \%\end{array}$ & $\begin{array}{l}7 \\
5.78 \%\end{array}$ & $\begin{array}{l}9 \\
6.25 \%\end{array}$ & $\begin{array}{l}7 \\
5.42 \%\end{array}$ & $\begin{array}{l}8 \\
5.63 \%\end{array}$ & $\begin{array}{l}7 \\
5.51 \%\end{array}$ \\
\hline T2DM STDR & $\begin{array}{l}131 \\
2.6 \%\end{array}$ & $\begin{array}{l}125 \\
2.5 \%\end{array}$ & $\begin{array}{l}132 \\
2.48 \%\end{array}$ & $\begin{array}{l}134 \\
2.49 \%\end{array}$ & $\begin{array}{l}141 \\
2.67 \%\end{array}$ & $\begin{array}{l}170 \\
2.68 \%\end{array}$ & $\begin{array}{l}162 \\
2.88 \%\end{array}$ & $\begin{array}{l}174 \\
2.84 \%\end{array}$ & $\begin{array}{l}139 \\
2.76 \%\end{array}$ \\
\hline T1DM DM0 & $\begin{array}{l}2 \\
1.71 \%\end{array}$ & $\begin{array}{l}3 \\
2.58 \%\end{array}$ & $\begin{array}{l}3 \\
2.47 \%\end{array}$ & $\begin{array}{l}4 \\
3.22 \%\end{array}$ & $\begin{array}{l}3 \\
2.47 \%\end{array}$ & $\begin{array}{l}5 \\
3.47 \%\end{array}$ & $\begin{array}{l}3 \\
2.32 \%\end{array}$ & $\begin{array}{l}4 \\
2.81 \%\end{array}$ & $\begin{array}{l}4 \\
3.15 \%\end{array}$ \\
\hline T2DM DMO & $\begin{array}{l}104 \\
2.00 \%\end{array}$ & $\begin{array}{l}101 \\
2.02 \%\end{array}$ & $\begin{array}{l}112 \\
2.11 \%\end{array}$ & $\begin{array}{l}114 \\
2.12 \%\end{array}$ & $\begin{array}{l}110 \\
2.08 \%\end{array}$ & $\begin{array}{l}150 \\
2.36 \%\end{array}$ & $\begin{array}{l}135 \\
2.40 \%\end{array}$ & $\begin{array}{l}153 \\
2.49 \%\end{array}$ & $\begin{array}{l}122 \\
2.42 \%\end{array}$ \\
\hline
\end{tabular}

Values are presented as number or mean \pm SD and range; also, we describe the incidence of DR and its different types.

DMO, diabetic macular oedema; DR, diabetic retinopathy; STDR, sight-threatening diabetic retinopathy; T1DM, type 1 diabetes mellitus; T2DM, type 2 diabetes mellitus. 


\section{Study of incidence of DR}

A total of 173 patients with T1DM (47.26\%) developed any-DR at 9 years with mean annual incidence of 15.16 $\pm 2.19 \%$ (13.67\%-15.97\%), 3982 patients with T2DM developed any-DR (26.49\%) with a mean annual incidence of $8.13 \%$ (7.06\%-8.9\%) (figure $1 \mathrm{~A}$ and table 1).

Sum incidence of STDR in patients with T1DM was $18.03 \%$ with an annual incidence of $5.77 \pm 1.21 \%(5.13 \%-6.45 \%)$ and

Table 2 Values of $\mathrm{HbA1C}$ and incidence of diabetic retinopathy (DR), according to duration of diabetes mellitus (DM)

\begin{tabular}{llll}
\hline $\begin{array}{l}\text { DM duration } \\
\text { (years) }\end{array}$ & DR incidence patients (\%) & HbA1c & \\
\hline$<5$ & $15(14.70)$ & No DR & $7.74 \pm 1.19 \%$ \\
& & Any-DR & $10.45 \pm 1.61 \%$ \\
& & Mean & $8.01 \pm 1.47 \%$ \\
$5-10$ & $36(41.86)$ & No DR & $7.85 \pm 1.78 \%$ \\
& & Any-DR & $8.93 \pm 1.78 \%$ \\
$10-15$ & $32(54.37)$ & Mean & $8.03 \pm 1.82 \%$ \\
& & No DR & $8.11 \pm 2.56 \%$ \\
& & Any-DR & $9.57 \pm 1.47 \%$ \\
$15-20$ & $30(66.66)$ & Mean & $8.48 \pm 2.41 \%$ \\
& & No DR & $7.39 \pm 0.51 \%$ \\
& & Any-DR & $8.93 \pm 1.47 \%$ \\
& & Mean & $7.91 \pm 1.68 \%$ \\
& & No DR & $7.54 \pm 0.82 \%$ \\
& & Any-DR & $8.57 \pm 1.41 \%$ \\
& & Mean & $7.94 \pm 1.19 \%$ \\
\hline
\end{tabular}

sum incidence in patients with T2DM was $7.59 \%$ with an annual incidence of $2.64 \pm 0.15 \%(2.48 \%-2.88 \%)$.

Sum incidence of DMO in patients with T1DM was $8.46 \%$ with an annual incidence of $2.68 \pm 038 \%(1.71 \%-3.22 \%)$ and sum incidence in T2DM was $6.36 \%$ with an annual incidence of $2.19 \pm 0.18 \%(2 \%-2.49 \%)$.

At the end of the study, all patients with T1DM were visited, and we did not find any new patient with DR; therefore, we confirmed that no patient had been misdiagnosed during the screening follow-up.

\section{Statistical analysis at the end of study}

In the univariate analysis (table 3), male gender, age at diagnosis HDL cholesterol and triglycerides are not significant. All other variables are significant: current age $p<0.001$, diabetes duration $\mathrm{p}<0.001$, presence of arterial hypertension $\mathrm{p}<0.001, \mathrm{HbA} 1 \mathrm{c}$ $\mathrm{p}<0.001$, LDL cholesterol $\mathrm{p}=0.02$, creatinine $\mathrm{p}=0.012$, UACR $\mathrm{p}<0.003$, eGFR $\mathrm{p}<0.001$ and UACR $(>30 \mathrm{mg} / \mathrm{g})+\mathrm{eGFR}$ $\left(<60 \mathrm{~mL} / \mathrm{min} / 1.73 \mathrm{~m}^{2}\right) \mathrm{p}<0.001$.

In Cox's proportional regression analysis (table 4 and figure 1B), the introduction of different variables with DM duration as a time variable changes the univariate statistical study. Current age remains significant at $\mathrm{p}<0.001$, probably due to the oldest patients having a longer duration of diabetes, therefore with more time to develop DR. Similar age at diagnosis was significant at $p<0.001$ with an HR value of 90.622. Gender remains not significant in the survival analysis.

Metabolic DM control measured by $\mathrm{HbA1c}$ values was a significant risk variable at $\mathrm{p}<0.001$, with an $\mathrm{HR}$ value of 12.53 . In the lipid study, LDL cholesterol remains a significant variable at $\mathrm{p}<0.001$ and an HR of 13.289. No other lipid variables (HDL
Figure 1 (A) Incidence of diabetic retinopathy (DR) and its severity. (B) Survival analysis graphs.
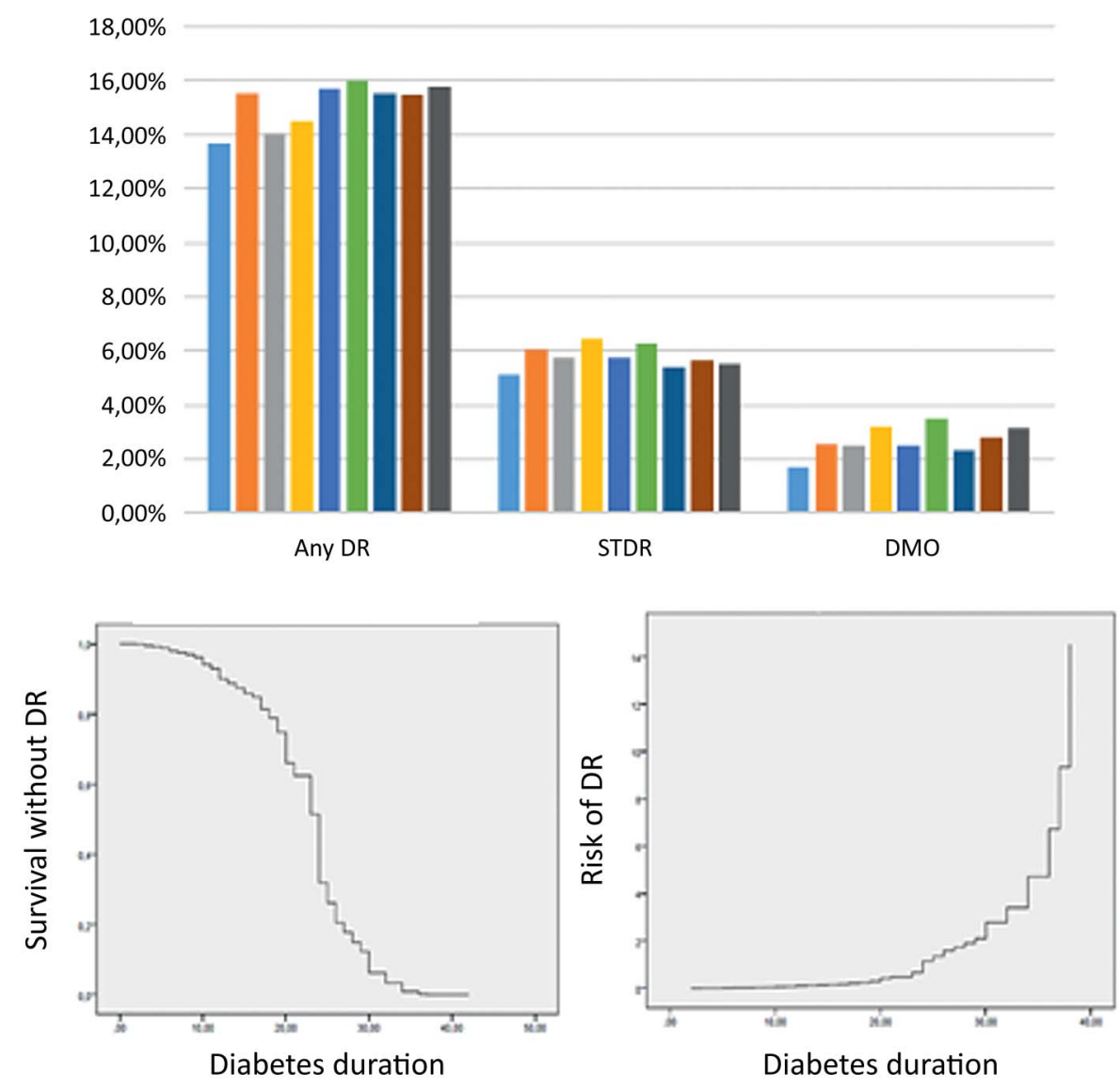
Table 3 Statistical analysis at the end of 9-year follow-up study, based on the 366 patients with T1DM studied

\begin{tabular}{|c|c|c|c|}
\hline & Mean values & Two-tailed Student's t-test/ANOVA & Univariate study \\
\hline \multicolumn{4}{|l|}{ Age } \\
\hline No DR & $34.16 \pm 10.4$ & & \\
\hline DR & $38.6 \pm 7.85$ & $p=0.004, F=8.41$ & $\mathrm{p}=0.004, \mathrm{OR} 2.94(95 \% \mathrm{Cl} 1.78$ to 4.86$)$ \\
\hline \multicolumn{4}{|l|}{ Male } \\
\hline No DR & $46.97 \%$ & & \\
\hline $\mathrm{DR}$ & $48.23 \%$ & & $\mathrm{p}=0.901$, OR 2.35 (95\% Cl 1.25 to 4.39 \\
\hline \multicolumn{4}{|c|}{ Age at diagnosis } \\
\hline No DR & $22.3 \pm 9.13$ & & \\
\hline $\mathrm{DR}$ & $21.2 \pm 8.4$ & $\mathrm{p}=0.301, \mathrm{~F}=1.28$ & $\mathrm{p}=0.175, \mathrm{OR} 1.22(95 \% \mathrm{Cl} 0.84$ to 1.78$)$ \\
\hline \multicolumn{4}{|c|}{ Diabetes duration } \\
\hline No DR & $11.6 \pm 8.63$ & & \\
\hline DR & $17.06 \pm 9.43$ & $\mathrm{p}<0.001, \mathrm{~F}=2.54$ & $\mathrm{p}<0.001$, OR 2.94 (95\% Cl 1.78 to 4.86$)$ \\
\hline \multicolumn{4}{|c|}{ Arterial hypertension } \\
\hline No DR & $9.61 \%$ & & \\
\hline $\mathrm{DR}$ & $28.23 \%$ & & $\mathrm{p}<0.001$, OR 3.70, (95\% Cl 1.99 to 6.85$)$ \\
\hline \multicolumn{4}{|l|}{$\mathrm{HbA1c}$} \\
\hline No DR & $7.76 \pm 1.6$ & & $\mathrm{p}<0.001$, OR 2.93 (95\% Cl 1.57 to 5.46 ) \\
\hline $\mathrm{DR}$ & $9.06 \pm 1.63$ & $p<0.001, F=13.75$ & \\
\hline \multicolumn{4}{|l|}{ LDL } \\
\hline No DR & $96.74 \pm 25.55$ & & \\
\hline $\mathrm{DR}$ & $100.88 \pm 27.15$ & $p=0.005, F=1.23$ & $\mathrm{p}=0.02$, OR $1.28(95 \%$ Cl 0.86 to 1.89$)$ \\
\hline \multicolumn{4}{|l|}{ HDL } \\
\hline No DR & $73.91 \pm 18.93$ & & \\
\hline DR & $62.05 \pm 19.33$ & $p=0.525, F=0.52$ & $\mathrm{p}=0.671,0 R 1.14(95 \% \mathrm{Cl} 0.60$ to 2.19$)$ \\
\hline \multicolumn{4}{|c|}{ Triglycerides } \\
\hline No DR & $96.08 \pm 41.64$ & & \\
\hline $\mathrm{DR}$ & $110.79 \pm 27.15$ & $p=0.059, F=3.59$ & $\mathrm{p}=0.383$, OR 0.91 (95\% Cl 0.62 to 1.35$)$ \\
\hline \multicolumn{4}{|l|}{ Creatinine } \\
\hline No DR & $0.77 \pm 0.16$ & & \\
\hline $\mathrm{DR}$ & $0.84 \pm 0.18$ & $p=0.002, F=2.54$ & $\mathrm{p}=0.012, \mathrm{OR} 1.65$ (95\% Cl 1.07 to 2.53$)$ \\
\hline \multicolumn{4}{|l|}{ UACR } \\
\hline No DR & $19.13 \pm 11.6$ & & \\
\hline $\mathrm{DR}$ & $28.38 \pm 39.24$ & $\mathrm{p}=0.003, \mathrm{~F}=2.48$ & $\mathrm{p}<0.001$, OR $3.82(95 \% \mathrm{Cl} 1.82$ to 8.03$)$ \\
\hline \multicolumn{4}{|l|}{ eGFR } \\
\hline No DR & $106.11 \pm 15.62$ & & \\
\hline $\mathrm{DR}$ & $85.08 \pm 17.01$ & $p<0.001, F=1.54$ & $\mathrm{p}<0.001$, OR 2.23 (95\% Cl 0.36 to 13.58$)$ \\
\hline
\end{tabular}

cholesterol or triglycerides) were significant in the survival analysis. The renal function study is interesting. Creatinine had a significant value in the univariate analysis, but not significant in the survival analysis $(\mathrm{p}=0.142)$. On the contrary, UACR remains a significant variable at $\mathrm{p}=0.017$ in the survival analysis, but eGFR was a more significant variable than UACR at $\mathrm{p}<0.001$ and an HR of 4.044 , only surpassed by age at diagnosis and current age, those DM duration-dependent variables. Also the association of $U A C R>30 \mathrm{mg} / \mathrm{g}$ and $e G F R<60 \mathrm{~mL} / \mathrm{min} / 1.73 \mathrm{~m}^{2}$ were significative at $\mathrm{p}<0.001$ and an HR of 3.329 .

\section{DISCUSSION}

This study should be judged in the context of previous authors' studies. ${ }^{7} 10$ The difference between patients with T1DM and T2DM according to the incidence of any-DR, which was higher in the T1DM group with annual incidence of $15.16 \pm 2.19 \%$ compared with $8.37 \pm 2.19 \%$ in T2DM, is difficult to compare our results with other studies; there are few studies that determine incidences of DR in T1DM and T1DM in the same population. We think that most similar with our study is the Scottish
National Diabetic Retinopathy Screening Programme ${ }^{11}$ that reports a higher cumulative incidence in patients with T1DM $(21.7 \%)$ than in those with T2DM (13.3\%) in the group without DR at baseline.

The incidence of STDR was higher in patients with T1DM at $5.77 \pm 0.67 \%$ compared with $2.65 \pm 0.15 \%$ in patients with T2DM, similar values to the Scottish study. ${ }^{11}$ STDR might be due to DMO or ischaemic retina secondary to severe DR; in this study, if we subtract patients with DMO of total STDR we can conclude that $3.55 \%$ of patients with T1DM have STDR due other causes than DMO; this percentage is higher than $0.45 \%$ in patients with T2DM. Therefore, there were more patients with STDR probably due to retinal ischaemia in T1DM.

Higher STDR values in T1DM are probably due to a longer duration of DM $(13.63 \pm 8.42$ years in patients with T1DM compared with $8.25 \pm 6.1$ years in patients with T2DM). In addition, bad metabolic control, measured by HbA1c $(8.38 \pm 1.16 \%$ in patients with T1DM compared with $7.38 \pm 1.29 \%$ in patients with T2DM), causes a higher incidence of DR in patients with T1DM. 
Table 4 Multivariate analysis, using Cox's proportional regression analysis

\begin{tabular}{|c|c|c|c|c|c|}
\hline Variable & $\begin{array}{l}\text { Significance HR } \\
(95 \% \mathrm{Cl})\end{array}$ & $\begin{array}{l}\text { Significance HR } \\
(95 \% \mathrm{Cl})\end{array}$ & $\begin{array}{l}\text { Significance HR } \\
(95 \% \mathrm{Cl})\end{array}$ & $\begin{array}{l}\text { Significance HR } \\
(95 \% \mathrm{Cl})\end{array}$ & $\begin{array}{l}\text { Significance HR } \\
(95 \% \mathrm{Cl})\end{array}$ \\
\hline Current age & $\begin{array}{l}\mathrm{p}<0.001 \text { HR } 0.736 \\
\text { (0.689 to } 0.787 \text { ) }\end{array}$ & $\begin{array}{l}\mathrm{p}<0.001 \text { HR } 0.738 \\
\text { (0.689 to } 0.789)\end{array}$ & $\begin{array}{l}p<0.001 \text { HR } 0.730 \\
\text { (0.681 to } 0.782)\end{array}$ & $\begin{array}{l}p<0.001 \text { HR } 0.715 \\
(0.665 \text { to } 0.770)\end{array}$ & $\begin{array}{l}p<0.001 \text { HR } 0.762 \\
\text { (0.684 to } 0.804 \text { ) }\end{array}$ \\
\hline Sex & $\begin{array}{l}p=0.871 \text { HR } 1.038 \\
\text { (0.658 to } 1.638)\end{array}$ & $\begin{array}{l}p=0.285 \text { HR } 1.305 \\
\text { (0.801 to } 2.125 \text { ) }\end{array}$ & $\begin{array}{l}\mathrm{p}=0.218 \text { HR } 1.361 \\
\text { (0.833 to } 2.222 \text { ) }\end{array}$ & $\begin{array}{l}p=0.780 \text { HR } 1.074 \\
\text { (0.651 to } 1.772)\end{array}$ & $\begin{array}{l}p=0.073 \text { HR } 1.573 \\
\text { (0.668 to } 1.988)\end{array}$ \\
\hline Age of DM diagnosis & $\begin{array}{l}\mathrm{p}<0.001 \text { HR } 1.387 \\
\text { (1.295 to } 1.485)\end{array}$ & $\begin{array}{l}\mathrm{p}<0.001 \text { HR } 1.389 \\
\text { (1.295 to } 1.489 \text { ) }\end{array}$ & $\begin{array}{l}\mathrm{p}<0.001 \text { HR } 1.402 \\
\text { (1.305 to } 1.506)\end{array}$ & $\begin{array}{l}p<0.001 \text { HR } 1.432 \\
\text { (1.330 to } 1.542 \text { ) }\end{array}$ & $\begin{array}{l}\mathrm{p}<0.001 \text { HR } 1.342 \\
\text { (1.294 to } 1.665)\end{array}$ \\
\hline Arterial hypertension & $\begin{array}{l}\mathrm{p}=0.055 \text { HR } 1.837 \\
(0.987 \text { to } 3.421)\end{array}$ & $\begin{array}{l}p=0.065 \text { HR } 1.061 \\
\text { (0.899 to } 3.872 \text { ) }\end{array}$ & $\begin{array}{l}p=0.096 \text { HR } 1.740 \\
\text { (0.907 to } 3.340)\end{array}$ & $\begin{array}{l}p=0.980 \text { HR } 1.009 \\
\text { (0.517 to } 1.970)\end{array}$ & $\begin{array}{l}\mathrm{p}=0.349 \text { HR } 1.367 \\
\text { (0.662 to } 1.899 \text { ) }\end{array}$ \\
\hline $\mathrm{HbA1c}$ & $\begin{array}{l}\mathrm{p}<0.001 \text { HR } 4.201 \\
\text { (2.156 to } 8.184)\end{array}$ & $\begin{array}{l}\mathrm{p}<0.001 \text { HR } 4.567 \\
(2.305 \text { to } 9.050)\end{array}$ & $\begin{array}{l}\mathrm{p}<0.001 \text { HR } 4.819 \\
\text { (2.411 to } 9.632)\end{array}$ & $\begin{array}{l}p<0.001 \text { HR } 3.456 \\
\text { (1.739 to } 6.868)\end{array}$ & $\begin{array}{l}\mathrm{p}<0.001 \text { HR } 2.211 \\
\text { (1.739 to } 6.868)\end{array}$ \\
\hline LDL cholesterol & $\begin{array}{l}\mathrm{p}<0.001 \text { HR } 0.981 \\
\text { (0.972 to } 0.991)\end{array}$ & $\begin{array}{l}p<0.001 \text { HR } 0.983 \\
\text { (0.974 to } 0.992)\end{array}$ & $\begin{array}{l}p<0.001 \text { HR } 0.984 \\
\text { (0.975 to } 0.993)\end{array}$ & $\begin{array}{l}p<0.001 \text { HR } 0.982 \\
\text { (0.973 to } 0.992)\end{array}$ & $\begin{array}{l}p=0.011 \text { HR } 0.987 \\
\text { (0.978 to } 1.095 \text { ) }\end{array}$ \\
\hline HDL cholesterol & $\begin{array}{l}\mathrm{p}=0.697 \text { HR } 1.000 \\
\text { (0.997 to } 1.002)\end{array}$ & $\begin{array}{l}\mathrm{p}=0.747 \text { HR } 1.000 \\
\text { (0.997 to } 1.002 \text { ) }\end{array}$ & $\begin{array}{l}p=0.656 \text { HR } 0.999 \\
\text { (0.997 to } 1.002 \text { ) }\end{array}$ & $\begin{array}{l}\mathrm{p}=0.724 \text { HR } 0.999 \\
\text { (0.996 to } 1.003 \text { ) }\end{array}$ & $\begin{array}{l}\mathrm{p}=0.653 \text { HR } 0.999 \\
\text { (0.995 to } 1.004)\end{array}$ \\
\hline Triglycerides & $\begin{array}{l}p=0.697 \text { HR } 0.999 \\
\text { (0.995 to } 1.003 \text { ) }\end{array}$ & $\begin{array}{l}p=0.337 \text { HR } 0.998 \\
\text { (0.993 to } 1.002)\end{array}$ & $\begin{array}{l}\mathrm{p}=0.151 \text { HR } 0.996 \\
(0.991 \text { to } 1.001)\end{array}$ & $\begin{array}{l}\mathrm{p}=0.166 \text { HR } 0.996 \\
\text { (0.990 to } 1.002)\end{array}$ & $\begin{array}{l}p=0.272 \text { HR } 0.997 \\
\text { (0.989 to } 1.011)\end{array}$ \\
\hline Creatinine & & $\begin{array}{l}p=0.005 \text { HR } 6.924 \\
\text { (1.813 to } 6.450 \text { ) }\end{array}$ & $\begin{array}{l}p=0.011 \text { HR } 5.560 \\
\text { (1.496 to } 3.410)\end{array}$ & $\begin{array}{l}p=0.287 \text { HR } 0.483 \\
\text { ( } 0.127 \text { to } 1.844 \text { ) }\end{array}$ & $\begin{array}{l}p=0.118 \text { HR } 0.937 \\
(0.255 \text { to } 2.189)\end{array}$ \\
\hline UACR & & & $\begin{array}{l}p=0.008 \text { HR } 2.354 \\
\text { (1.251 to } 4.431)\end{array}$ & $\begin{array}{l}p=0.017 \text { HR } 2.144 \\
\text { (1.144 to } 4.018 \text { ) }\end{array}$ & \\
\hline eGFR & & & & $\begin{array}{l}p<0.001 \text { HR } 4.044 \\
\text { (2.716 to } 6.022)\end{array}$ & \\
\hline UACR+eGFR & & & & & $\begin{array}{l}p<0.001 \text { HR } 3.329 \\
\text { (1.977 to } 5.877)\end{array}$ \\
\hline
\end{tabular}

UACR+eGFR=if UACR was $>30 \mathrm{mg} / \mathrm{g}$ and eGFR $<60 \mathrm{~mL} / \mathrm{min} / 1.73 \mathrm{~m}^{2}$

DM, diabetes mellitus; eGFR, estimated glomerular filtration rate; UACR, urine albumin to creatinine ratio.

The incidence of DMO shows similar percentages in both types of DM, with a mean of $2.68 \pm 0.38 \%(1.71 \%-3.22 \%)$ in patients with T1DM and $2.22 \pm 0.19 \%(2 \%-2.49 \%)$ in patients with T2DM, despite final sum incidence was higher in patients with T1D $(8.46 \%)$ than those with T2DM (6.36\%).

Higher any-DR values in T1DM perhaps can be explained by two different causes: (i) a longer duration of DM (13.63 \pm 8.42 years in patients with T1DM compared with 8.25 \pm 6.1 years in patients with T2DM) and (ii) bad metabolic control measured by HbA1c $(8.38 \pm 1.16 \%$ in patients with T1DM compared with $7.38 \pm 1.29 \%$ in patients with T2DM).

The incidence of any-DR according to DM was $14.7 \%$ of patients with $<5$ years' duration. This is important data for screening programmes, which generally include a revision at 5 years if no DR is present in T1DM, perhaps we must change review time lapse after onset of T1DM.

Also in this study, only $81.08 \%$ patients with a DM duration of $>20$ years developed DR. In recent studies, it is frequent to observe a decrease in the incidence of DR in this group of patients, thus the Wisconsin Diabetes Registry Study, ${ }^{12}$ which reported a $92 \%$ prevalence of any-DR, lower than previous studies such as the Wisconsin Epidemiological Study of Diabetic Retinopathy, which reported values of $97 \% .^{13}$ A possible explanation for these differences, shown in table 2 , is that patients with DM duration of over 15 years have a better metabolic control with low levels of HbA1c.

The lipid study shows that LDL cholesterol is a risk factor in the present sample of patients. Lipid studies often create controversy, such as the Yau et $a l^{14}$ meta-analysis, which reported that higher total cholesterol was linked to DMO, and similar data were reported by the fenofibrate study, ${ }^{15}$ which reported slow progression and development of DR with the use of fenofibrates.

Kidney function can be evaluated by UACR or eGFR, both values being linked to DR. ${ }^{16}$ Changes in eGFR occur prior to an increase in UACR. The eGFR increases in early-stage DM and decreases in advanced stages, reflecting the decline in renal function. Recently, eGFR was determined using the CKD-EPI equation. In this study, it is evident that the eGFR is more significant than creatinine values. Furthermore, UACR seems less significant than the eGFR in Cox's survival regression (table 3). Perhaps microalbuminuria secondary to arterial hypertension or infection makes a masquerade effect in UACR. Determination of CKD-EPI equation as a reference for eGFR is recommended by various medical societies. ${ }^{17} \mathrm{~A}$ cohort study by Man et $a l^{18}$ reported a significant relationship between CKD-EPI values and DMO. From our data, we would encourage further studies to determine the CKD-EPI equation in patients with T1DM as an important DR risk marker.

At the end of this study, we found that $47.26 \%$ patients developed DR. These data contrast with our previously published study: ${ }^{10}$ on a sample size of 334 patients with T1DM, in which only 120 developed DR at 10 years (35.32\%). The differences might be explained by methodology and the lower mean HbA1c levels in the previous study of $7.7 \pm 1.42 \%$ than this study $(8.38$ $\pm 1.16 \%$ ), probably due to a relaxation in metabolic control of patients with T1DM in recent years. ${ }^{10}$ A value of $47.26 \%$ sum incidence at 9 years is also higher than other published studies, such as Martín-Merino et al, ${ }^{19}$ based on a UK population, with a $23.9 \%$ at 9 years, and Leske et al, ${ }^{20}$ published in 2006 and based on a population in Barbados, with an incidence of $39.6 \%$. Perhaps, higher HbA1c levels in this study might have caused these differences.

At the end of study, we revised all 366 patients to determine if any developed DR and was not reported previously during study, but we observed that no one of patients registered as normal fundus developed DR, which can demonstrate the validity of our screening programme. However, we must remember 
that a study of the peripheral retina can detect more lesions and can change the severity of retinopathy. ${ }^{21}$

Including patients with T1DM in a T2DM screening programme is feasible but it is important to remember that more frequent screening is difficult to achieve.

Current T2DM screening, with a mean of $4.11 \pm 0.77$ visits over a 9-year period, implies that a patient visits only every 2.18 years, despite the recommendation for patients with T1DM being annual from 5 years on. ${ }^{22} 23$ Patients and clinicians should aim to make yearly retinography checks 5 years after the onset of T1DM. ${ }^{24}$

A limitation of our study is the small sample of 366 patients with T1DM and 15030 patients with T2DM in our screened population. The number of patients with T1DM who developed DR over the 9-year follow-up period was 173 (47.26\% of the sample), but the increase or decrease of only one patient can change the results in a $0.28 \%$. The number of patients, who developed STDR, and especially DMO, is small and can bias the statistical analysis.

Strengthens of our study are (i) the screening programme, in which patients with T1DM of our area are being included; at present, there are few studies on the incidence of DR in T1DM; Lee et $a l^{25}$ carried out a literature review in 2015 but there were only six referenced studies of DR incidence in patients with T1DM; (ii) also, the long follow-up period of our T1DM population; and (iii) the large amount of data, such as lipid profile and GFR. It is important that future studies investigate the CKD-EPI equation, as a marker of eGFR for DR development. The increase in any-DR (47.26\%) compared with our previous study $(35.9 \%)$ is another important consideration, because it would seem to be linked to bad metabolic control of T1DM. If our results are confirmed by other studies in different populations, we might expect to treat a lot of complications in DR in the future.

Acknowledgements The authors thank all paediatricians, general practitioners and endocrinologists in our area who have helped us to implement the new screening system using the non-mydriatic fundus camera, and our camera technicians for their work and interest in the diabetes screening.

Contributors PRA: contributed to study conception and design, collected research data, reviewed the statistical analysis, wrote the discussion and edited the manuscript, contributing to the final approval of the version sent for publication. RN-G: contributed to study conception and design, contributed to ophthalmological data collection, diagnosed diabetic macular oedema, carried out the laboratory procedures, wrote the discussion and made a critical review, contributing to the final approval of the version sent for publication. AV-M: contributed to study design and the statistical analysis, interpreted the research data, made a critical review and reviewed the translation, contributing to the final approval of the version sent for publication. RS-A: contributed to study conception and design, contributed to diabetes mellitus data collection, carried out the retinographies, interpreted the research data and helped to write the manuscript, contributing to the final approval of the version sent for publication. AM-R: contributed to study design and the statistical analysis, interpreted research data and contributed to the interpretation of the study findings, contributing to the final approval of the version sent for publication. NS: contributed to ophthalmological data collection, carried out retinographies and OCT procedures and interpreted the research data, contributing to the final approval of the version sent for publication.

Funding This study was funded by research projects F112/01535 June 2013 and FI15/01150 July 2015 (Instituto de Investigaciones Carlos III (IISCIII) of Spain), and FEDER funds.

Competing interests None declared.

Ethics approval Hospital Universitario Sant Joan de Reus Ethics Committee [approval no. 13-01-31/proj6].

Provenance and peer review Not commissioned; externally peer reviewed.

Open Access This is an Open Access article distributed in accordance with the Creative Commons Attribution Non Commercial (CC BY-NC 4.0) license, which permits others to distribute, remix, adapt, build upon this work non-commercially, and license their derivative works on different terms, provided the original work is properly cited and the use is non-commercial. See: http://creativecommons.org/ licenses/by-nc/4.0/

\section{REFERENCES}

1 International Diabetes Federation. IDF diabetes Atlas. 6th edn. Brussels, Belgium, 2013. http://www.idf.org/diabetesatlas

2 The Expert Committee on the Diagnosis and Classification of Diabetes Mellitus. Report of the Expert Committee on the Diagnosis and Classification of Diabetes Mellitus. Diabetes Care 2000;23(Suppl 1):S4-19.

3 Bourne RR, Jonas JB, Flaxman SR, et al., Vision Loss Expert Group of the Global Burden of Disease Study. Prevalence and causes of vision loss in high-income countries and in Eastern and Central Europe: 1990-2010. Br J Ophthalmol 2014;98:629-38

4 Li R, Zhang P, Barker LE, et al. Cost-effectiveness of interventions to prevent and control diabetes mellitus: a systematic review. Diabetes Care 2010;33:1872-94.

5 American Diabetes Association. (9) Microvascular complications and foot care. Diabetes Care 2015:38:S58-66.

6 Romero P, Sagarra R, Ferrer J, et al. The incorporation of family physicians in the assessment of diabetic retinopathy by non-mydriatic fundus camera. Diabetes Res Clin Pract 2010;88:184-8

7 Romero-Aroca P, de la Riva-Fernandez S, Valls-Mateu A, et al. Changes observed in diabetic retinopathy: eight-year follow up of a Spanish population. $\mathrm{Br} J$ Ophthalmol 2016:100:1366-71.

8 Aldington SJ, Kohner EM, Meuer S, et al. Methodology for retinal photography and assessment of diabetic retinopathy: the EURODIAB IDDM complications study. Diabetologia 1995:38:437-44.

9 ETDRS. Detection of diabetic macular oedema study no 5. Ophthalmology 1989:9:746-51.

10 Romero-Aroca P, Baget-Bernaldiz M, Fernandez-Ballart J, et al. Ten-year incidence of diabetic retinopathy and macular edema. Risk factors in a sample of people with type 1 diabetes. Diabetes Res Clin Pract 2011;94:126-32.

11 Looker HC, Nyangoma SO, Cromie DT, et al., Scottish Diabetes Research Network Epidemiology Group; Scottish Diabetic Retinopathy Collaborative. Rates of referable eye disease in the Scottish National Diabetic Retinopathy Screening Programme. Br J Ophthalmol 2014;98:790-5.

12 LeCaire TJ, Palta M, Klein R, et al. Assessing progress in retinopathy outcomes in type 1 diabetes: comparing findings from the Wisconsin Diabetes Registry Study and the Wisconsin Epidemiologic Study of Diabetic Retinopathy. Diabetes Care 2013:36:631-7.

13 Klein R, Klein BE, Moss SE, et al. The Wisconsin epidemiologic study of diabetic retinopathy. III. Prevalence and risk of diabetic retinopathy when age at diagnosis is 30 or more years. Arch Ophthalmol 1984;102:527-32.

14 Yau JW, Rogers SL, Kawasaki R, et al., Meta-Analysis for Eye Disease (META-EYE) Study Group. Global prevalence and major risk factors of diabetic retinopathy. Diabetes Care 2012;35:556-64.

15 Simó R, Roy S, Behar-Cohen F, et al. Fenofibrate: a new treatment for diabetic retinopathy. Molecular mechanisms and future perspectives. Curr Med Chem 2013;20:3258-66.

16 Romero-Aroca P, Baget-Bernaldiz M, Reyes-Torres J, et al. Relationship between diabetic retinopathy, microalbuminuria and overt nephropathy, and twenty-year incidence follow-up of a sample of type 1 diabetic patients. J Diabetes Complicat 2012;26:506-12.

17 Levey AS, Stevens LA, Schmid CH, et al., CKD-EPI (Chronic Kidney Disease Epidemiology Collaboration). A new equation to estimate glomerular filtration rate. Ann Intern Med 2009;150:604-12.

18 Man RE, Sasongko MB, Wang JJ, et al. The association of estimated glomerular filtration rate with diabetic retinopathy and macular edema. Invest Ophthalmol Vis Sci 2015;56:4810-16.

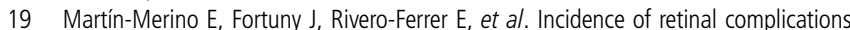
in a cohort of newly diagnosed diabetic patients. PLOS ONE 2014;9:e100283.

20 Leske MC, Wu SY, Hennis A, et al. Nine-year incidence of diabetic retinopathy in the Barbados Eye Studies. Arch Ophthalmol 2006;124:250-5

21 Silva PS, Cavallerano JD, Sun JK, et al. Peripheral lesions identified by mydriatic ultrawide field imaging: distribution and potential impact on diabetic retinopathy severity. Ophthalmology 2013;120:2587-95.

22 Diabetes (type 1 and type 2) in children and young people: diagnosis and management. NICE guideline (NG18) Published date: Last updated: November 2016. https://www.nice.org.uk/guidance/ng18/chapter/1Recommendations\# type-1-diabetes

23 American Diabetes Association. Microvascular complications and foot care. Diabetes Care 2016;39(Suppl 1):S72-80.

24 Scanlon PH, Aldington SJ, Leal J, et al. Development of a cost-effectiveness model for optimisation of the screening interval in diabetic retinopathy screening. Health Technol Assess 2015;19:1-116.

25 Lee R, Wong TY, Sabanayagam C. Epidemiology of diabetic retinopathy, diabetic macular edema and related vision loss. Eye Vis (Lond) 2015;2:17 